\title{
GLOBALISATION SCEPTICISM IN THE VISEGRAD COUNTRIES
}

\author{
MARIANNA DUDÁŠOVÁ ${ }^{1}$
}

\section{Globalizačný skepticizmus v krajinách Vyšehradu}

\begin{abstract}
Recent developments in the European Union revealed significant differences between the Visegrad countries and the remaining members of the EU. The enlargement euphoria of the first decade of the 21 st century was replaced by certain enlargement fatigue, manifesting itself not only in concrete governmental policies but also in the public opinion towards the EU. As European integration and globalisation are parallel processes, declining support for European integration must not necessarily be the result of disagreement with specific policies and should be examined in the broader context of globalisation fears and anxieties. The article describes variations in globalisation scepticism between the group of Visegrad countries and the remaining countries of the EU as well as variations within the Visegrad group itself, focusing on the main drivers of economic globalisation - international trade, foreign direct investment, and immigration. The development of public opinion since the financial and economic crisis in 2009 indicates that Visegrad countries should not be treated as a uniform bloc of globalisation sceptics as there are significant differences in opinion between the more pessimistic Czechs and Slovaks and the more optimistic Poles and Hungarians. Their globalisation scepticism also varies across different dimensions of globalisation and is fuelled by different motivations.
\end{abstract}

Keywords: globalisation scepticism, international trade, foreign direct investment, immigration, Visegrad countries, KOF Globalisation Index

JEL Classification: F10, F15, F21, F22, F60

\footnotetext{
${ }^{1}$ Ing. Marianna Dudášová, PhD., Pan-European University in Bratislava, Slovak Republic, e-mail: marianna.dudasova@paneurouni.com, ORCID ID https://orcid.org/0000-0002-7865-8561
} 


\section{Globalisation backlash}

Characterized by deeply intertwined forms of cooperation and complex dependencies across countries of the globe, globalisation is a deeply controversial phenomenon because it is an uneven process that does not necessarily work for all. As the cleavages between those benefiting and those losing from globalisation become more tangible, scepticism or even downright hostility towards globalisation are on the rise. Bewildered especially with the pace of change and the current turmoil in the global environment, many blame globalisation for all the crises we currently face be them of socio-economic, political or security nature. The era of political and overall public sentiments driven by a "globalisation euphoria" (Hübner et al., 2017) promoted mainly by international economic circles and multilateral institutions (Singh, 1997), is over. Not insignificant shares of the public see globalisation as a harmful and disruptive process and thus show only limited willingness to engage in the global economy (White, 2017), opting rather for nationalist or protectionist policies. In Europe, fears of globalisation are the main force behind the populist backlash (Vries and Hoffman, 2016) as a growing number of people do not believe they are benefiting from globalisation or simply feel overwhelmed and left behind (Kuhn, 2019). Consequently, they vote for those who can skillfully articulate their anxieties. These developments are heavily challenging the assertion of the transactionalist theory formulated by Deutsch and his colleagues in the 1950s (cited in Kuhn, 2011; Kuhn, 2019) that positive consequences of increased economic and political cooperation between states will trigger support for and legitimate supranational cooperation and integration.

Past decades were characterized by dramatic increases in both the intensity and the diversity of international migration, trade, and investment flows (White, 2017). These have brought a lot of opportunities as well as challenges and provoked heated debates on inequality between those who have so far been benefiting from globalisation and those who suffered from its destructing symptoms, e. g. losing their jobs, facing stagnating real wages, or increased cultural diversity. If benefits should outweigh the costs and the gains are to be distributed inclusively, international cooperation and balanced government policies are inevitable (Ernst and Haar, 2019). Moreover, the general public must be confident that such policies are possible and that governments can pursue and implement them successfully. After WWII countries in Western 
Europe opted for an intensified cooperation and established institutions that should coordinate government policies to handle issues of supranational nature more effectively. Countries of Central and Eastern Europe, being a part of the socialist realm, were excluded from this cooperation until the 1990s. After the end of the Cold War, the EU membership was seen as a key element on their path to becoming fully integrated within the global community. While the indisputable achievements of the EU membership are still valued and recognized as great successes of the political and economic transformation processes, the decade since the global economic crisis of 2009 revealed reservations towards the global community, the complexities of globalisation and its immense social implications (Schmölz, 2019).

Among Central and Eastern Europe countries, the Visegrad group, comprising Czechia, Hungary, Poland, and Slovakia, has recently gained a reputation of a protest group, articulating increasingly critical messages concerning European integration and hindering the development of common European positions and policy responses in important matters, the refugee and migration crisis being the most prominent example (Végh, 2018). Considering the exceptional pace of (especially) economic integration and globalisation processes in the Visegrad countries, as shown throughout the article, it is not necessarily surprising that people in these countries struggle with adapting to the immanent contradictions of globalisation. While Visegrad countries are often described as eurosceptic, be it from the perspective of party politics (e. g. Tereszkiewicz, 2018; Duro, 2016; Henderson, 2008) or public opinion (Flamm, 2012; Guerra, 2013), these attitudes could also be examined within a broader context of globalisation scepticism. Globalisation and European integration are parallel processes creating a wide array of opportunities but also causing increased economic uncertainty and competition, massive immigration flows and other disruptive effects. These cannot always be unambiguously attributed to one or the other phenomenon, thus it seems plausible that declining support for European integration is not always and necessarily a result of disagreement with specific European Union policies and should rather be seen and examined in the broader context of globalisation fears and anxieties. Those who fear globalisation are much more suspicious of politics in general and European integration in particular (Vries and Hoffman, 2016). As Kuhn (2011) argues, globalisation waters down the legitimacy of European integration and may mask the impact of transnationalism on EU support at the individual level. 
Based on these assumptions, the main aim of the article is to describe variations in globalisation scepticism between the group of Visegrad countries and the remaining countries of the European Union as well as variations within the Visegrad group itself. We use several Eurobarometer surveys to answer the question of whether there are significant differences in globalisation perceptions between respondents from the Visegrad countries and other EU member countries. Besides the attitudes towards globalisation in general, the article focuses on individuals' perceptions of the most important aspects of economic globalisation - international trade, foreign direct investment, and immigration.

\section{Intensity and drivers of globalisation in Visegrad countries}

The belief that globalisation is a recent phenomenon is a common misconception (Ernst and Haar, 2019). It can rather be described as an ongoing process, occurring, and operating unevenly in time and space (MacKinnon and Cumbers, 2007). It refers to interconnections between states, societies, businesses, or people and describes processes by which events, decisions, and activities in one part of the world can affect individuals and communities in other parts of the globe. While such linkages existed long before the term globalisation was coined, the modern globalised era is characterized by a dramatic increase not only in the scope (stretching) but also in the intensity (deepening) of these processes (Amin and Thrift, 1997). Consequently, the concept of globalisation has taken centre stage in recent discussions about the world economy (MacKinnon and Cumbers, 2007). A general shift towards increased international economic cooperation and integration can be observed since the 1970s (White, 2017) and stimulated in particular by the end of the bipolar world in the 1990s (Swiss Economic Institute, 2021). To estimate the extent of this acceleration, we can use the KOF index, the most widely used and cited globalisation rate measure, calculated regularly by the Swiss Economic Institute. It is a composite index measuring the intensity of globalisation along its economic, social, and political dimension for every country in the world. It distinguishes between de facto and de jure measures and ranges in value from 0 (not at all globalized) to 100 (very much globalized). Currently available data span the period from 1970 through 2018. The average score in the economic dimension of the index rose from 37,08 in 1970 to 45,03 in 1990 (increase by 
$21,5 \%$ ) and 57,59 in 2010 (increase by 27,9\%). Since then, the score increased only by $2,4 \%$ to 58,83 in $2018 .^{2}$

As shown in Figure 1, economic globalisation was boosted following the end of the Cold War. Looking at the Visegrad countries (V4) we see only slow and minor changes until the $1990 \mathrm{~s}^{3}$ but a dramatic change in economic globalisation intensity within two decades between the end of the Cold War and the global economic crisis of 2009. When comparing the V4 group data with the remaining EU countries, there is only a minor difference standing in 2018 - the V4 average score being 80,01 and the average of EU28 without the V4 countries being $81,18 .^{4}$

Figure 1: KOF Index of Economic Globalisation (1970 - 2018)

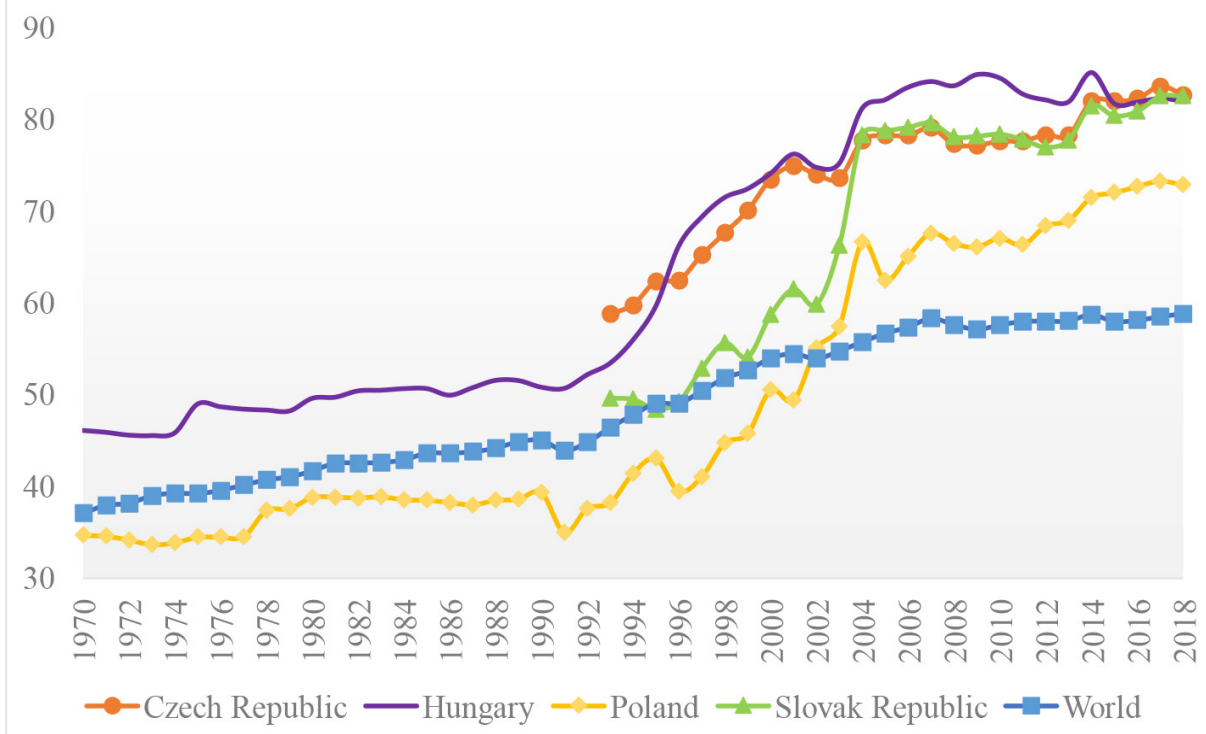

Source: own processing based on data from the Swiss Economic Institute (2021)

However, as we can see from Figure 2, the difference was already small before these countries joined the EU in 2004. We can conclude that the level, as well as pace of economic globalisation in the Visegrad countries, remains comparable with the rest of the EU since then. The process of catching up was concentrated in the $1990 \mathrm{~s}$ and the first years of the $21^{\text {st }}$ century.

\footnotetext{
${ }^{2}$ In 1970 the KOF Globalisation index covered 141 countries, in 1990175 countries, in 2010 and 2018 196 countries.

${ }^{3}$ Until 1993 only data for Poland and Hungary are available. There is no data for the Czech and the Slovak Republic which emerged in 1993 after the dissolution of Czechoslovakia.

${ }^{4}$ European Union as of 2018, i. e. EU28.
} 
Figure 2: KOF Index of Economic Globalisation in EU countries (1993 2018)

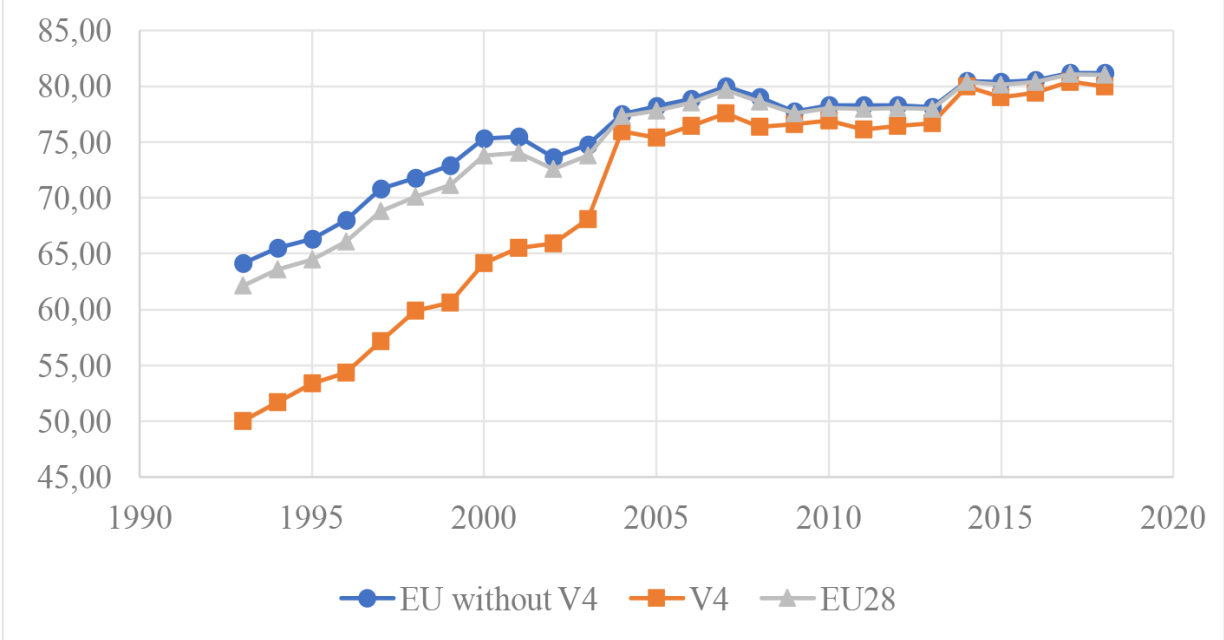

Source: own processing based on data from the Swiss Economic Institute (2021)

Table 1 reveals that the economic dimension was the main driver of globalisation with an increase in the KOF score by almost 60\% between 1993 and 2018, followed by social globalisation (35\%) and political globalisation $(18 \%)$. This is more than double the pace in the remaining EU member states (as of 2018). At the same time, we can see an almost identical pace of these two groups in the political dimension and a somewhat higher pace in the social dimension. Looking at the structured data of the KOF Index, we can identify three areas with the highest acceleration of global interconnectedness - financial (78\%), interpersonal (54\%) and trade globalisation (46\%). ${ }^{5}$ To put it simply, investment, migration, and foreign trade were the most important drivers of globalisation in the Visegrad region since the 1990s. Thus, we will focus on public attitudes in Visegrad countries regarding these three facets of globalisation. ${ }^{6}$

\footnotetext{
${ }^{5}$ For a detailed overview of the respective variables, see the KOF Index Methodology available online and Gygli et al. (2019): The KOF Globalisation Index - Revisited.

${ }^{6}$ Migration is considered by the KOF Index as being a part of the social dimension of globalisation, however it could be broadly described as a socioeconomic phenomenon which cannot be clearly attributed to economic or social dimension only.
} 
Table 1: Globalisation in Visegrad countries along KOF Index dimensions (1993 and 2018)

\begin{tabular}{|c|c|c|c|c|}
\hline KOF Index & Countries & 1993 & 2018 & increase (in \%) \\
\hline \multirow{2}{*}{ Globalization Overall } & V4 & 61,41 & 82,76 & $34,77 \%$ \\
\hline & EU28 w/o V4 & 67,95 & 84,55 & $24,43 \%$ \\
\hline \multirow{2}{*}{ Economic Globalization } & V4 & 50,03 & 80,01 & $59,93 \%$ \\
\hline & EU28 w/o V4 & 64,14 & 81,18 & $26,57 \%$ \\
\hline \multirow{2}{*}{ Trade Globalization } & V4 & 56,41 & 82,29 & $45,87 \%$ \\
\hline & EU28 w/o V4 & 63,82 & 81,08 & $27,04 \%$ \\
\hline \multirow{2}{*}{ Financial Globalization } & V4 & 43,64 & 77,73 & $78,12 \%$ \\
\hline & EU28 w/o V4 & 64,46 & 81,34 & $26,18 \%$ \\
\hline \multirow{2}{*}{ Social Globalization } & V4 & 59,00 & 79,37 & $34,54 \%$ \\
\hline & EU28 w/o V4 & 65,83 & 84,50 & $28,37 \%$ \\
\hline \multirow{2}{*}{ Interpersonal Globalization } & V4 & 46,93 & 72,50 & $54,47 \%$ \\
\hline & EU28 w/o V4 & 65,60 & 81,33 & $23,98 \%$ \\
\hline \multirow{2}{*}{ Informational Globalization } & V4 & 58,02 & 81,18 & $39,90 \%$ \\
\hline & EU28 w/o V4 & 61,74 & 86,28 & $39,75 \%$ \\
\hline \multirow{2}{*}{ Cultural Globalization } & V4 & 72,03 & 84,44 & $17,23 \%$ \\
\hline & EU28 w/o V4 & 70,14 & 85,88 & $22,44 \%$ \\
\hline \multirow{2}{*}{ Political Globalization } & V4 & 75,21 & 88,90 & $18,21 \%$ \\
\hline & EU28 w/o V4 & 73,85 & 87,96 & $19,12 \%$ \\
\hline
\end{tabular}

Source: own processing based on data from the Swiss Economic Institute (2021)

\section{Attitudes towards globalisation in Visegrad countries}

We use data from several Eurobarometer surveys conducted between 2009 2019 to assess the extent of scepticism toward selected aspects of economic globalisation in the Visegrad countries and to answer the question of whether there are significant differences between this group and the remaining members of the European Union or across the group itself. As a starting point, we use longitudinal country-level data from standard Eurobarometer surveys on individual perceptions of globalisation as an opportunity or threat for economic growth. 
Figure 3: Individual perceptions of globalisation in the EU (2009-2019)

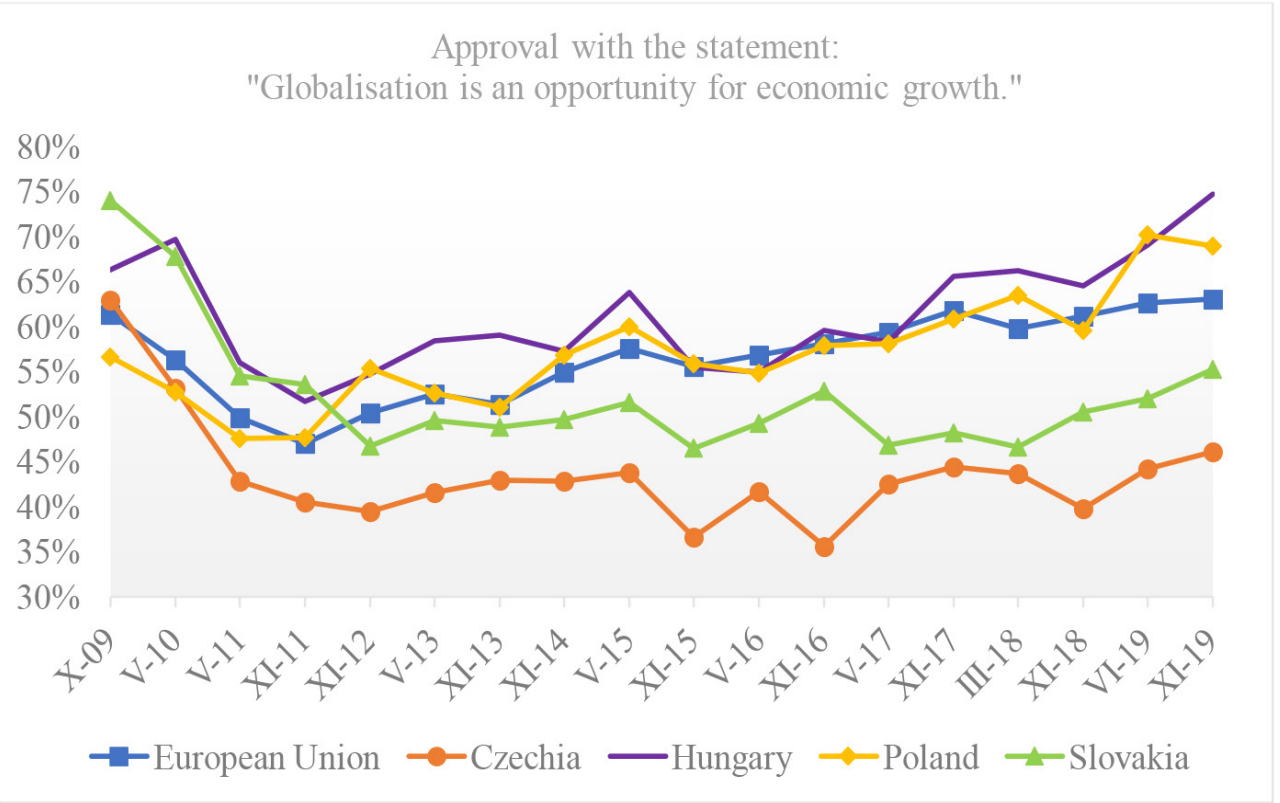

Source: own processing based on data from standard Eurobarometer surveys, explored via the Eurobarometer Interactive tool.

As Figure 3 shows, after the global economic crisis in 2009, there was a significant decline in the positive perception of globalisation as an opportunity for economic growth across the EU. Since 2011, this optimistic perception of globalisation is once again on the rise among EU citizens and has recently even exceeded pre-crisis values ( $+2 p p)$. Before the crisis, the citizens of all Visegrad countries except for Poland were more optimistic than EU citizens on average. At present, optimism remains fairly below the EU average and below the pre-crisis national levels in Slovakia (-18,7 pp) and Czechia (-16,9 pp). In contrast, optimism has surged in Hungary $(+8,4 \mathrm{pp})$ and Poland $(+12,3$ $\mathrm{pp})$.

Examining individual-level data from a Eurobarometer survey on attitudes towards trade and trade policy (European Commission, 2019) we can see quite mixed perceptions of globalisation benefits and drawbacks. The most widespread attitude (32\%) towards globalisation is that it brings new export and investment opportunities for businesses, but almost the same proportion of EU citizens (30\%) also think that it is changing the world too quickly and people are powerless to stop it. The belief that globalisation results in a wider 
choice of goods and lower prices have a very similar approval rate and the same goes for the statement that globalisation is only benefiting big business (both 29\%). Differences between respondents from Visegrad countries and other EU member states are not striking. The most significant variances can be observed regarding the perception of a wider choice of products, where respondents from Visegrad display more positive views $(+5,7 \mathrm{pp})$ and concerning our powerlessness towards globalisation $(+5,4 \mathrm{pp})$ where the same respondents display more pessimism.

Table 2: Opinion on globalisation in European Union countries (2019

\begin{tabular}{|c|c|c|c|c|}
\hline \multirow[b]{2}{*}{$\begin{array}{l}\text { Opinion on } \\
\text { globalisation }\end{array}$} & \multirow[b]{2}{*}{ Statement } & \multicolumn{3}{|c|}{ Approval with statement } \\
\hline & & $\begin{array}{c}\text { EU28 } \\
\text { w/o V4 }\end{array}$ & V4 & EU28 \\
\hline \multirow{4}{*}{ Positive } & $\begin{array}{l}\text { It brings new export and investment } \\
\text { opportunities for businesses }\end{array}$ & $32,9 \%$ & $29,7 \%$ & $32,4 \%$ \\
\hline & $\begin{array}{l}\text { It results in a wider choice of goods in } \\
\text { the shops and lower prices }\end{array}$ & $28,8 \%$ & $34,5 \%$ & $29,5 \%$ \\
\hline & $\begin{array}{l}\text { It creates jobs in export businesses } \\
\text { and their suppliers }\end{array}$ & $27,7 \%$ & $28,1 \%$ & $27,8 \%$ \\
\hline & $\begin{array}{l}\text { It has transformed the lives of } \\
\text { hundreds of millions of people in } \\
\text { developing countries by lifting them } \\
\text { out of poverty }\end{array}$ & $21,2 \%$ & $21,7 \%$ & $21,3 \%$ \\
\hline \multirow{4}{*}{ Negative } & $\begin{array}{l}\text { It is changing our world too quickly, } \\
\text { but we are powerless to stop it }\end{array}$ & $29,1 \%$ & $34,5 \%$ & $29,8 \%$ \\
\hline & It only benefits big business & $29,4 \%$ & $29,7 \%$ & $29,4 \%$ \\
\hline & $\begin{array}{l}\text { Governments find it difficult to } \\
\text { control }\end{array}$ & $28,6 \%$ & $26,0 \%$ & $28,2 \%$ \\
\hline & $\begin{array}{l}\text { It threatens jobs, our way of life and } \\
\text { the environment }\end{array}$ & $26,5 \%$ & $25,3 \%$ & $26,3 \%$ \\
\hline \multirow{2}{*}{ Neutral } & $\begin{array}{l}\text { It has been happening for centuries } \\
\text { and will probably continue to happen }\end{array}$ & $22,9 \%$ & $26,1 \%$ & $23,3 \%$ \\
\hline & $\begin{array}{l}\text { It has both advantages and } \\
\text { disadvantages }\end{array}$ & $3,8 \%$ & $1,1 \%$ & $3,5 \%$ \\
\hline
\end{tabular}

Source: own processing by SPSS and Microsoft Excel, based on the Special Eurobarometer 491 survey (Europeans' attitude on Trade and EU trade policy) (European Commission, 2019). Data are weighted by WEIGHT EXTRAPOLATED POPULATION AGED 15+. Red colour (Italic type style) indicates the more negative and green colour (Bold type style) the more positive group in terms of various globalisation aspects. 
Looking at the total data summarizing the overall perception of globalisation in Table 3, we see respondents almost evenly divided between the positives $(62 \%)$ and negatives of globalisation (58\%). Considering the V4 countries as a group, positives outweigh negatives in a similar proportion, but this varies considerably by country. The most pronounced difference between the proportions of positive and negative items can be observed in Czechia (58\% positive compared with $78 \%$ negative). On the other hand, Polish respondents showed the highest level of optimism with an 11-pp difference in favour of positive perceptions. In Slovakia and Hungary, pessimistic views are slightly stronger (by 5 and 3 pp respectively).

Table 3: Overall perception of globalisation in European Union countries (2019)

\begin{tabular}{|c|c|c|c|r|}
\hline \multirow{2}{*}{ Country } & \multicolumn{3}{|c|}{ Perceptions of Globalisation } \\
\cline { 2 - 5 } & Positive & Negative & \multicolumn{2}{c|}{ Difference } \\
\hline Visegrad countries (V4) & $\mathbf{6 6 , 1 \%}$ & $\mathbf{6 3 , 0} \%$ & & $3,1 \%$ \\
\hline Poland & $68,9 \%$ & $58,1 \%$ & & $10,8 \%$ \\
\hline Hungary & $66,4 \%$ & $68,8 \%$ & & $-2,5 \%$ \\
\hline Slovakia & $61,1 \%$ & $66,0 \%$ & & $-4,9 \%$ \\
\hline Czech Republic & $58,2 \%$ & $73,9 \%$ & & $-15,7 \%$ \\
\hline EU28 w/0 V4 & $60,8 \%$ & $57,2 \%$ & & $3,7 \%$ \\
\hline European Union & $61,5 \%$ & $57,9 \%$ & & $3,6 \%$ \\
\hline
\end{tabular}

Source: own processing by SPSS and Microsoft Excel, based on the Special Eurobarometer 491 survey (Europeans' attitude on Trade and EU trade policy) (European Commission, 2019). Data are weighted by WEIGHT EXTRAPOLATED POPULATION AGED 15+.

We now turn our attention to public attitudes regarding the three aspects of socio-economic globalisation identified in the second part of the article as the most important drivers of globalisation in the Visegrad region - trade, investment, and migration. 


\subsection{Public perceptions of international trade benefits}

Theories of international trade recognize the fact that while trade may be beneficial to the country, its effects on different segments of society may vary. The political economy of international trade usually explains public opinion on its usefulness in two theoretical approaches, based on the common assumption that an individuals' view of international trade will be shaped by how trade affects their income and well-being. For example, people working in sectors that are dependent on foreign markets will be greater supporters of free trade than people working in sectors that face significant competition in the form of imports. However, as Mansfield and Mutz (2009) point out, people often do not associate their socio-economic situation with a specific economic policy of the government and consequently assess policies according to their impact on the national economy. International trade can thus also be considered beneficial by a person whose own socio-economic situation has been adversely affected by it.

As shown in Table 4, there has been a significant increase in positive perception of individual benefits of international trade in the last decade. While in 2010 only $44 \%$ of respondents stated that they were benefiting a lot or somewhat from trade, in 2019 it was more than 60\%. However, there is a clear divergence visible between respondents from Visegrad countries and those from other EU countries. While the former group was slightly more pessimistic in 2010, it shows significantly more positive views about the benefits of trade in 2019 .

Table 4: Perceptions on individual benefits of international trade (2010 and 2019)

\begin{tabular}{|l|c|c|c|c|c|c|}
\hline \multirow{2}{*}{$\begin{array}{c}\text { INTERNATIONAL } \\
\text { TRADE - INDIVIDUAL } \\
\text { BENEFIT }\end{array}$} & $\mathbf{2 0 1 0}$ & & & \multicolumn{2}{|c|}{$\mathbf{2 0 1 9}$} \\
\cline { 2 - 7 } & $\begin{array}{c}\text { EU28 } \\
\text { w/o V4 }\end{array}$ & V4 & EU28 & $\begin{array}{c}\text { EU28 } \\
\text { w/o V4 }\end{array}$ & V4 & EU28 \\
\hline Yes, benefitting a lot & $9,6 \%$ & $6,5 \%$ & $9,2 \%$ & $19,7 \%$ & $16,6 \%$ & $19,3 \%$ \\
\hline Yes, benefitting somewhat & $34,9 \%$ & $36,7 \%$ & $35,1 \%$ & $39,5 \%$ & $53,3 \%$ & $41,3 \%$ \\
\hline No, not really benefitting & $23,0 \%$ & $23,3 \%$ & $23,1 \%$ & $19,6 \%$ & $15,7 \%$ & $19,1 \%$ \\
\hline No, not benefitting at all & $16,0 \%$ & $16,7 \%$ & $16,1 \%$ & $14,5 \%$ & $7,6 \%$ & $13,6 \%$ \\
\hline DK & $16,5 \%$ & $16,7 \%$ & $16,5 \%$ & $6,6 \%$ & $6,8 \%$ & $6,7 \%$ \\
\hline Total & $\mathbf{1 0 0 , 0 \%}$ & $\mathbf{1 0 0 , 0} \%$ & $\mathbf{1 0 0 , 0} \%$ & $\mathbf{1 0 0 , 0} \%$ & $\mathbf{1 0 0 , 0} \%$ & $\mathbf{1 0 0 , 0} \%$ \\
\hline
\end{tabular}

Source: own processing by SPSS and Microsoft Excel, based on the Special Eurobarometer 357 survey (International Trade) (European Comission, 2010) and Special Eurobarometer 491 survey (Europeans' attitude on Trade and EU trade policy) (European Commission, 2019). Data are weighted by WEIGHT EXTRAPOLATED POPULATION AGED 15+. 
Explanatory note: The Chi-square test of independence confirmed a statistically significant $(\mathrm{p}=0.000)$ relationship between the respondents 'affiliation to the Visegrad group and their perceptions of individual benefits of international trade both in 2010 and 2019, with a very weak effect size in 2010 (Cramer's V $=0.037)$ and small effect size in 2019 (Cramer's $\mathrm{V}=0.103)$.

However, there are relatively significant differences within the Visegrad group itself - while in Poland and Hungary approximately $73 \%$ of respondents felt individual benefits from trade in 2019, in Slovakia, it was 69\% and in Czechia only $57 \%$. The largest increase in positive perceptions of trade since 2010 was observed in Poland (+33 pp), followed by Hungary (+24 pp), Slovakia $(+18$ pp) and Czechia (+10 pp).

The most prominent reasons for individually benefiting from trade among respondents from V4 countries were that trade results in a wider choice for consumers (56\%), lower prices of products $(31 \%)$ and that it is good for the European economy (24\%). However, there was a significant decline since 2010 in the approval with the statement that imported products are cheaper (-15pp). Approval with all other types of benefits rose among respondents from V4. In other EU countries, the three main reasons for individually benefiting from international trade are the same, though, there is a stronger approval rate regarding the positive effects of trade on prices $(37 \%)$ and overall positive impact on the European economy (31\%). The statement with the highest level of divergence between respondents from these two groups is that imported products are of better quality - this opinion has become stronger in V4 countries but is diminishing in other EU member states. In 2019, one in five respondents from V4 countries would agree with this, while only less than one in ten in the remaining EU member states.

Respondents from the V4, who stated in 2019 that they did not benefit from international trade, most often cited rising prices of imported products $(37 \%)$, declining product quality (36\%) and an overall bad impact on the European economy (21\%). Interestingly, the number of those who are concerned with the negative impact of international trade on the environment has almost doubled since 2010 (from 10 to 19\%). In other EU countries, the most frequently mentioned reasons for not benefiting from trade were those concerning the negative impact on unemployment and the quality of imported products (26\% both), as well as rising product prices (25\%). Compared to the 2010 survey, the opinions of respondents from V4 countries and other EU member states regarding the negative environmental impact of trade have converged substantially. On the contrary, there is a greater variance of opinions on rising 
prices and the decline in product quality - V4 respondents displayed more concerns by $12 \mathrm{pp}$ and $10 \mathrm{pp}$, respectively.

To conclude, respondents from the V4 display more optimism regarding the benefits of international trade, more often citing reasons directly influencing their socio-economic situation, while the less optimistic respondents from other EU countries more often mention the impact of trade on the European economy as such, its job market and environment.

\subsection{Public support for international investment activities}

Data on public perceptions of foreign investment activities is rather rare but thanks to the Special Eurobarometer survey on attitudes towards trade and trade policy (European Commission, 2019) we can examine public views on foreign direct investment (FDI) from outside the EU as well as in the opposite direction - investment from the EU in third countries. Respondents in this survey were first asked two questions to express support or opposition towards businesses from outside the EU investing or buying businesses in their country. A similar pair of questions were asked regarding their support for national businesses investing or buying businesses outside the EU. One could also say that these questions elicit survey respondents' views on the inflow and outflow of greenfield (building from the ground up) and brownfield (takeover of existing domestic production) FDI. Negative attitudes towards FDI are not necessarily an expression of nationalism or fear of cultural change, they can be based on concerns about detrimental economic consequences of any foreign involvement in an economy. Thus, one may expect greater opposition towards brownfield FDI that evokes a foreign takeover of domestic companies (White, 2017)

As Table 5 reveals, there is strong public support for greenfield investment from outside the EU (73\%) across all EU member states. The assumption of lower support for brownfield FDI was confirmed - acquisitions of domestic businesses by investors from outside the EU was supported by slightly less than half of the respondents. ${ }^{7}$ The differences between the Visegrad countries and other EU member states are statistically significant but rather small. Respondents from Visegrad show slightly more support for both greenfield and brownfield FDI.

\footnotetext{
${ }^{7}$ A crosstabulation of answers to both questions reveals that two out of three respondents supporting greenfield investment also support a brownfield investment. On the other hand, $85 \%$ of those opposing greenfield also oppose brownfield investment.
} 
Table 5: Public support in the EU for investment inflows and outflows (2019)

\begin{tabular}{|c|c|c|c|c|c|c|}
\hline \multirow{2}{*}{$\begin{array}{l}\text { Support for businesses } \\
\text { outside the EU }\end{array}$} & \multicolumn{3}{|c|}{$\begin{array}{l}\text { INVESTING IN } \\
\text { COUNTRY }\end{array}$} & \multicolumn{3}{|c|}{$\begin{array}{c}\text { BUYING BUSINESSES IN } \\
\text { COUNTRY }\end{array}$} \\
\hline & $\begin{array}{c}\text { EU } 28 \\
\text { w/o V4 }\end{array}$ & V4 & EU28 & $\begin{array}{c}\text { EU } 28 \\
\text { w/o V4 }\end{array}$ & V4 & EU28 \\
\hline Support & $72,5 \%$ & $74,7 \%$ & $72,8 \%$ & $48,9 \%$ & $51,6 \%$ & $49,3 \%$ \\
\hline Oppose & $21,2 \%$ & $18,7 \%$ & $20,9 \%$ & $44,3 \%$ & $41,8 \%$ & $44,0 \%$ \\
\hline \multirow{2}{*}{$\begin{array}{l}\text { Support for businesses } \\
\text { from country }\end{array}$} & \multicolumn{3}{|c|}{$\begin{array}{c}\text { INVESTING IN } \\
\text { COUNTRY OUTSIDE } \\
\text { THE EU }\end{array}$} & \multicolumn{3}{|c|}{$\begin{array}{c}\text { BUYING BUSINESSES IN } \\
\text { COUNTRY OUTSIDE } \\
\text { THE EU }\end{array}$} \\
\hline & $\begin{array}{c}\text { EU } 28 \\
\text { w/o V4 }\end{array}$ & $\mathrm{V4}$ & EU28 & $\begin{array}{c}\text { EU } 28 \\
\text { w/o V4 }\end{array}$ & V4 & EU28 \\
\hline Support & $65,2 \%$ & $71,4 \%$ & $66,0 \%$ & $59,5 \%$ & $68,4 \%$ & $60,6 \%$ \\
\hline Oppose & $28,2 \%$ & $21,7 \%$ & $27,4 \%$ & $32,8 \%$ & $23,1 \%$ & $31,5 \%$ \\
\hline
\end{tabular}

Source: own processing by SPSS and Microsoft Excel, based on the Special Eurobarometer 491 survey (Europeans' attitude on Trade and EU trade policy) (European Commission, 2019). Data are weighted by WEIGHT EXTRAPOLATED POPULATION AGED 15+.

A similar pattern of support can be observed in the case of investment outflows to countries outside the EU. At the EU level, the support is $66 \%$ for greenfield FDI and $61 \%$ for business acquisitions. Differences between respondents from Visegrad countries and other EU member states are slightly larger than in the case of investment inflow.

Country-level data within the V4 group reveal that an inter-group comparison of V4 and other EU countries can be misleading. While Czechia, Slovakia and Hungary show very similar and under-average levels of support for greenfield FDI (ranging from 63\% to 66\%), in Poland the support is significantly higher and well above the EU average (81\%). The differences in support for brownfield FDI from outside the EU are even more pronounced. Polish respondents showed the greatest support (60\%), followed by Slovaks (49\%), Hungarians (44\%) and Czechs (32\%). To conclude, public opinion in the V4 is less investment-friendly than in other EU countries, except for Poland with levels of support well above the EU average. 


\subsection{Public perceptions of immigration from outside the $E \mathbf{U}$}

Public opinion on immigrants is influenced by economic and non-economic factors. Economic factors commonly represent the perceived benefits and costs of immigration that are expected to be realized by the host country economy and its residents. These can be related to potential labour market consequences or impact on the host country welfare system (see e. g. Miller, 2012). Noneconomic factors, as a large body of literature shows, are even more important determinants of public opinion regarding immigration (see e. g. Facchini, Mayda and Puglisi , 2013 or Hainmueller and Hopkins, 2014). These can be related to a broad variety of socio-cultural changes that are expected by residents of the host country, ranging from positive ones such as enrichment of cultural life and increase in innovation potential to negative ones such as alienation or increased crime levels.

As shown in Figure 4, negative attitudes towards immigration from third countries intensified across Europe with the migration and refugee crisis of 2015. However, as early as 2016, the trend reversed, and we currently see a lower proportion of respondents with a negative perception of immigration from third countries than in 2014. In the V4, negative attitudes towards immigration are much more widespread. They are most present in Slovakia (76\%) and Czechia (75\%). The least objections to immigration were expressed by respondents from Poland (52\%). Except for Hungary, negative perceptions of immigrants are higher than in 2014.

To assess contemporary public views in the EU towards immigrants in more detail, we use data from the latest special Eurobarometer survey devoted to immigration and integration of immigrants in the EU (European Commission, 2018). We first examine general perceptions of immigration as an opportunity or as a threat and then the perceived impact of immigrants on the society of the host country and its residents.

Immigration from outside the EU is more of a problem than an opportunity according to $37 \%$ of EU citizens, however, in Visegrad countries this proportion is higher by more than $7 \mathrm{pp}$. Adding up the two categories seeing at least some opportunities in immigration, we can conclude that respondents from Visegrad showed less optimism (42\%) than those polled in other EU member states (53\%). From the scepticism perspective, almost three out of four respondents from V4 regard immigration from third parties at least partially as a problem. 
Figure 4: Attitudes towards immigration from outside the EU (2014 - 2019)

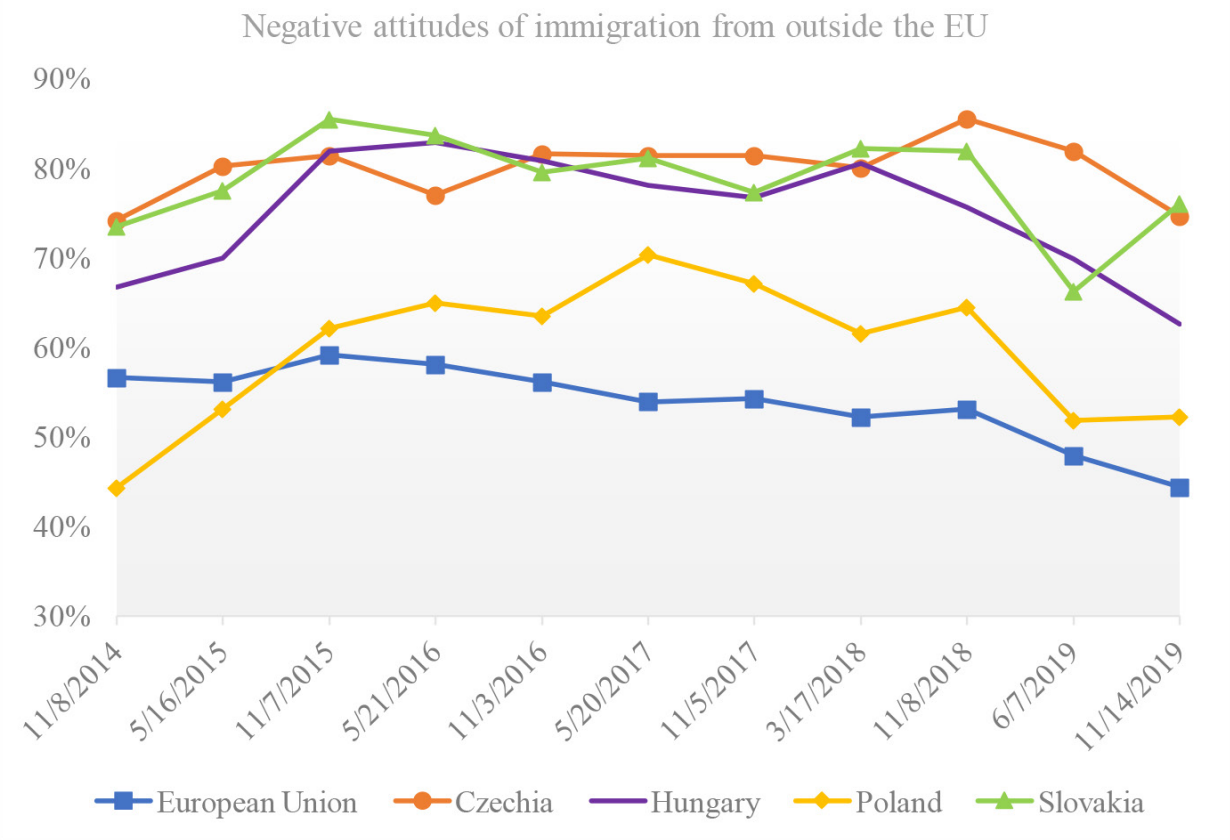

Source: Standard Eurobarometer question „Please tell me whether immigration of people from outside the EU evokes a positive or negative feeling for you". The graph shows a sum of "Fairly negative" and "Very negative" answers. Data were explored via the Eurobarometer Interactive tool.

Regarding the impact of immigrants on society as shown in Figure 4, there is a relatively strong consensus across the EU that immigrants are helping to close the gap in the national labour markets - three out of four respondents from EU countries outside Visegrad and 66\% from Visegrad agree with this statement. About half of the respondents in both groups also think that immigrants have a positive impact on their respective national economies. However, in the Visegrad countries, there are much greater fears that immigrants are taking jobs from the domestic population (53\% in Visegrad vs. $37 \%$ in the remaining EU countries) and there is a stronger belief that immigrants are a burden for the national welfare systems (63\% vs. 54\%). Even greater differences of opinion between the two groups exist concerning the social and cultural impacts of immigration. Respondents from Visegrad countries are significantly more sceptical to the immigrants' potential to bring new ideas and innovations to the country or enrich its cultural life. 
Table 6: Public perceptions of immigration from outside the EU (2017)

\begin{tabular}{|l|c|c|c|}
\hline \multirow{2}{*}{$\begin{array}{c}\text { IMMIGRATION FROM } \\
\text { OUTSIDE EU - PROBLEM OR } \\
\text { OPPORTUNITY }\end{array}$} & \multicolumn{2}{|c|}{ Group of countries } & \multirow{2}{*}{ Total } \\
\cline { 2 - 3 } $\begin{array}{c}\text { EU } \mathbf{2 8} \\
\text { w/o V4 }\end{array}$ & V4 & \\
\hline Immigration is more of a problem & $36,2 \%$ & $44,6 \%$ & $37,3 \%$ \\
\hline Immigration is more of an opportunity & $21,1 \%$ & $15,0 \%$ & $20,3 \%$ \\
\hline $\begin{array}{l}\text { Immigration is equally a problem and } \\
\text { an opportunity }\end{array}$ & $31,7 \%$ & $27,4 \%$ & $31,1 \%$ \\
\hline $\begin{array}{l}\text { Immigration is neither a problem nor } \\
\text { an opportunity }\end{array}$ & $8,0 \%$ & $8,1 \%$ & $8,0 \%$ \\
\hline DK & $2,9 \%$ & $5,0 \%$ & $3,2 \%$ \\
\hline Total & $\mathbf{1 0 0 , 0 \%}$ & $\mathbf{1 0 0 , 0 \%}$ & $\mathbf{1 0 0 , 0 \%}$ \\
\hline
\end{tabular}

Source: own processing by SPSS and Microsoft Excel, based on the Special Eurobarometer 469 survey (Integration of immigrants in the European Union) (European Commission, 2018). Data are weighted by WEIGHT EXTRAPOLATED POPULATION AGED 15+.

Explanatory note: The Chi-square test of independence confirmed a statistically significant $(\mathrm{p}=0.000)$ relationship between the respondents 'affiliation to the Visegrad group and their perception of immigration from outside the EU with a small size effect (Cramer's V = 0.08).

By examining and comparing country-level data, we can conclude that Czechs are most worried when it comes to socio-cultural influences - they associate migration with crime and do not believe in the enrichment of cultural life or the innovative potential of immigrants. Hungarians are the most sceptical within the V4 group regarding the positive economic effects of immigration from outside the EU and consider it rather as a burden for the country's welfare system. Slovaks are those most worried that immigrants could take away jobs from them. Poles have the most favourable view of immigrants from all Visegrad countries - they showed the highest degree of agreement with all positive statements regarding immigration impact and the highest level of disagreement with all negative statements, except for one - that immigrants take jobs away from workers. Similar findings about the differences among Visegrad countries have been made on the basis of European Social Survey data (see Bozogáňová et al., 2017). 
Figure 5: Individual perceptions of immigration impact in EU member countries (2017)

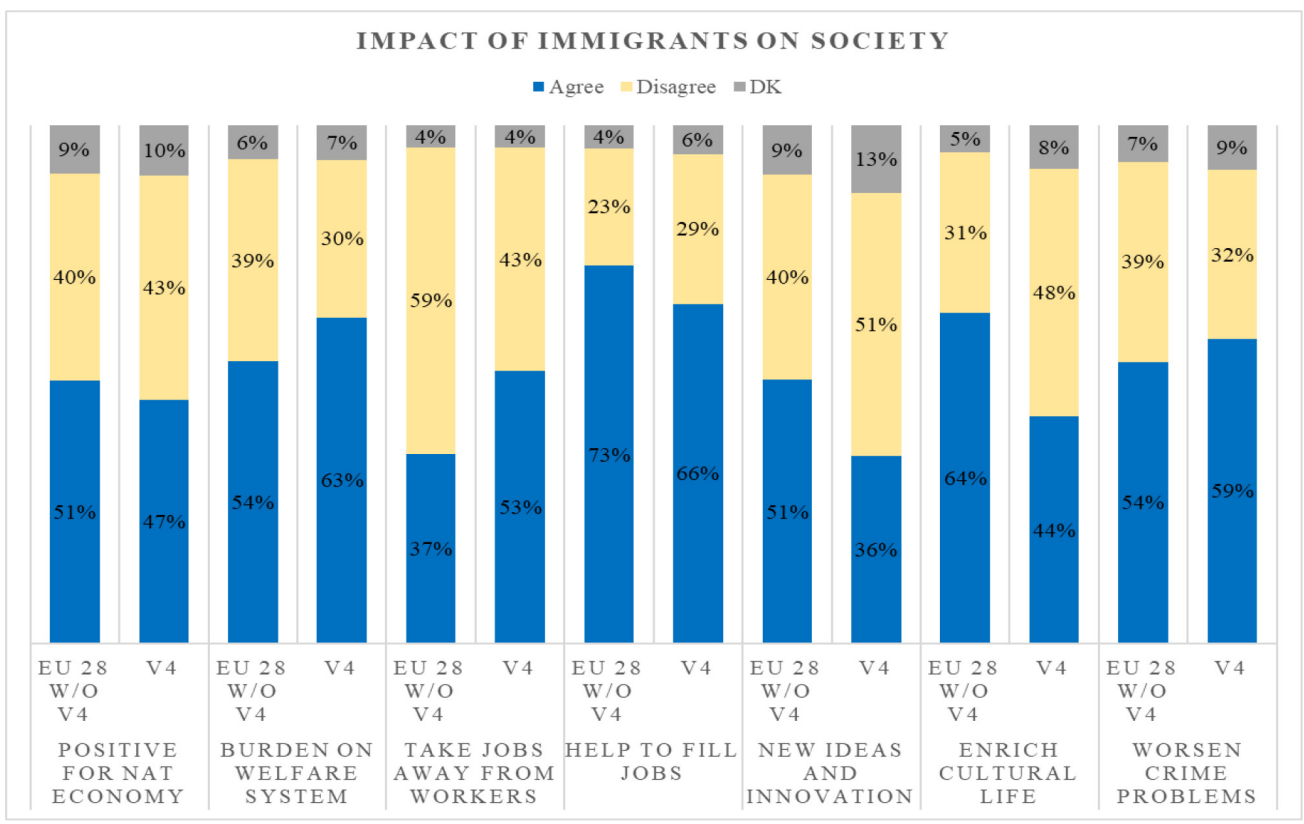

Source: own processing by SPSS and Microsoft Excel, based on the Special Eurobarometer 469 survey (Integration of immigrants in the European Union) (European Commission, 2018). Data are weighted by WEIGHT EXTRAPOLATED POPULATION AGED 15+.

Explanatory note: The Chi-square test of independence confirmed a statistically significant $(\mathrm{p}=0.000)$ relationship between the respondents 'affiliation to the Visegrad group and their attitudes on the impact of immigration from outside the EU. Two statements with highest size effects were „Immigrants enrich (national) cultural life" (Cramer's $\mathrm{V}=0.156$; medium size effect) and "Immigrants take jobs from workers" (Cramer's V $=0.126$; small size effect)

To conclude, people in the Visegrad countries see immigration from outside the EU more negatively than those from other countries and their negative perceptions are to a greater extent fueled by non-economic factors.

\section{Discussion and conclusion}

The most politically and economically advanced post-communist countries - Czechia, Hungary, Poland, and Slovakia - commonly referred to as Visegrad Group, have recently gained a reputation of a troublemaker refusing common European initiatives. Considering the remarkable pace 
of economic integration and globalisation processes in these countries in recent decades it is not surprising that people struggle with adapting to the complexities of globalisation and its enormous social implications. As socioeconomic insecurity and resentments triggered by the destructing symptoms of globalisation can sometimes be equalized with failures of the EU, they might water down the legitimacy and public support for European integration. Consequently, they should not be easily deterred as a mere populist backlash.

The article explored the question of whether the public image of the Visegrad countries as a protest group opposing supranational policy responses has been mirrored in a public opinion growing more sceptical towards globalisation since the global economic crisis of 2009. Not surprisingly, this event has had a significant impact on the perception of globalisation. However, the crisis-induced pessimism has proved to be temporary in most EU member states. When compared with an EU average, the proportion of those who see globalisation as an opportunity for economic growth is higher in Hungary and Poland but lower in Czechia and Slovakia where pessimism has been on the rise since the global economic crisis. Analysing individual-level data, we have found a quite ambivalent opinion on globalisation in the Visegrad countries, where people feel relatively more helpless against globalisation, but at the same time better appreciate some of its benefits, especially the wider choice of products. Overall, Poland, the least globalized country from the Visegrad group, has the most optimistic public, while Czechia, the most globalised country from the Visegrad group, has the most pessimistic public. Similar patterns of support have been identified concerning the main drivers of globalisation - trade, investment, and immigration. These results once again challenge the overly optimistic outlook of the transactionalist theory that increased transnational interactions trigger support for further political integration.

The global economic crisis has also affected public opinion on international trade. We found an EU-wide increase in individually perceived benefits from international trade, but in the Visegrad countries, this increase was significantly higher, especially in Poland and Hungary. What is also changing, are the reasons why individuals think they benefit or do not benefit from trade. The belief that trade leads to lower product prices has fallen sharply across the EU, but more dramatically in the V4 countries. On the other hand, people in V4 increasingly appreciate the positive effects of trade on product quality, while in other EU countries this conviction is becoming weaker. In contrast, positive 
macroeconomic and labour market effects of trade are more appreciated by individuals outside the V4.

EU-wide, there is strong support for the inflow as well as the outflow of greenfield investment and slightly weaker support for the inflow and outflow of brownfield investment. A between-groups comparison of the V4 and the remaining EU member states suggests slightly more support in the V4 group, but country-level data revealed a significant difference between Poles who show support levels well above the EU average and individuals from other V4 countries who are considerably less investment-friendly.

Negative attitudes towards immigration from third countries intensified across Europe in reaction to the migration and refugee crisis of 2015. While there is a relatively strong consensus across the EU that immigrants are helping to close the gap in the national labour markets and have a positive impact on the respective national economies, there are much greater fears in the Visegrad countries that immigrants are taking jobs from the domestic population and a stronger belief that immigrants are a burden for the national welfare systems. While Poles have the most favourable view of immigrants from all Visegrad countries, the strongest reservations have been expressed by Slovaks and Czechs. Slovaks are most worried that immigrants could take away jobs from them, while Czechs expressed strong sociotropic concerns about the cultural implications of immigration. Hungarians are the most sceptical about the economic effects of immigration, they tend to consider it rather as a burden for the country's welfare system.

Summarizing the results, public attitudes towards globalisation in the V4 countries are not uniform. We can essentially identify two blocs, the more pessimistic Czecho-Slovak bloc, and the more optimistic Polish-Hungarian bloc, sometimes displaying substantial discrepancies in the perception of globalisation benefits and drawbacks. This is a somewhat surprising finding, being at odds with the public image of Poland and Hungary. These countries have been repeatedly criticized by the EU for their illiberal governance models, non-conformal behaviour, and lack of solidarity. Their governments have been involved in several conflicts with the EU, indicating a severe clash of mindsets. On the one hand, a liberal cosmopolitan mindset emphasizing the value of open borders and shared multicultural values, on the other hand, a nativist mindset, favouring closed borders over the free flow of peoples, ideas, labour and capital, mono-culturalism over multiculturalism and 
national self-interest over international cooperation (Inglehart and Norris, 2016). However, our results indicate that the public in these countries does not seem to be excessively sceptical towards the main drivers of economic globalisation, except for migration. Consequently, one should be cautious to describe the Visegrad countries simply as globalisation sceptics. It is important to distinguish the attitudes articulated by the political elites and public opinion and consider variations among the members of the group. Various facets of globalisation and the possibility of different motivations (economic as well as non-economic) for globalisation scepticism should also be considered. Going beyond the descriptive nature of this study and identifying such motivations and their underlying causes requires further research and application of such statistical methods that would allow us to examine the existence of causal links between individual and group characteristics of respondents and their attitudes to globalisation.

\section{REFERENCES}

[1] Amin, A., \& Thrift, N. (1997). Globalisation, Socio-Economics, Territoriality. In R. Lee \& J. Wills (Eds.), Geographies of economies (pp. 147 - 157). Routledge.

[2] Bozogáňová, M., Lorincová, T., Magdová, M., \& Berinšterová, M. (2020). Comparison of Visegrad Four from the Viewpoint of Opinions on Immigrants. Psychological Applications and Trends 2020, $151-155$.

https://doi.org/10.36315/2020inpact032.pdf

[3] Duro, J. (2016). Becoming mainstream? Euroscepticism among established parties in V4 countries. Eurasian Journal of Social Sciences, 4(4), 35 - 47.

https://doi.org/10.15604/ejss.2016.04.04.003

[4] Ernst, R., \& Haar, J. (2019). Globalization, competitiveness, and governability: The three disruptive forces of business in the 21 st century. Palgrave Macmillan.

https://doi.org/10.1007/978-3-030-17516-0

[5] European Commission. (2010). Special Eurobarometer 357, Wave 74.1 - TNS Opinion \& Social. International Trade. Available

at: https://search.gesis.org/research_data/ZA5237

[6] European Commission. (2018). Special Eurobarometer 469, Wave EB88.2 - TNS Opinion \& Social. Integration of immigrants in the European Union. Available at: https://search.gesis.org/research_data/ZA6927

[7] European Commission. (2019). Special Eurobarometer 491, Wave EB91.4 - Kantar. Europeans' attitude on Trade and EU trade policy. Available at: https://search.gesis. org/research_data/ZA7575 
[8] Facchini, G., Mayda, A. M., \& Puglisi, R. (2013). Individual Attitudes towards Immigration: Economic vs. Non-Economic Determinants. In G. P. Freeman, R. Hansen, \& D. L. Leal (Eds.), Immigration and public opinion in liberal democracies (pp. 129-157). Routledge.

[9] Flamm, L. (2012). The crisis and Eurosceptism in Central and Eastern Europe. L'Europe En Formation, 364(2), 305 - 321. https://doi.org/10.3917/eufor.364.0305

[10] Guerra, S. (2013). Central and eastern European attitudes in the face of Union. Springer

[11] Gygli, S., Haelg, F., Potrafke, N., \& Sturm, J. E. (2019). The KOF globalisation index - revisited. The Review of International Organizations, 14(3), 543 - 574.

https://doi.org/10.1007/s11558-019-09344-2

[12] Hainmueller, J., \& Hopkins, D. J. (2014). Public attitudes toward immigration. Annual Review of Political Science, 17(1), 225 - 249. https://doi.org/10.1146/annurevpolisci-102512-194818

[13] Henderson, K. (2008). Exceptionalism or convergence? Euroscepticism and party systems in Central and Eastern Europe. In A. Szczerbiak \& P. Taggart (Eds.), Opposing Europe? The Comparative Party Politics of Euroscepticism: Volume 2: Comparative and Theoretical Perspectives (pp. 103-126). Oxford University Press.

[14] Inglehart, R., \& Norris, P. (2016). Trump, Brexit, and the Rise of Populism: Economic Have-Nots and Cultural Backlash. Harvard Kennedy School: Faculty Research Working Paper Series. Available at: https://papers.ssrn.com/sol3/papers.cfm?abstract $\mathrm{id}=2818659$

[15] Kuhn, T. (2011). Individual transnationalism, globalisation and euroscepticism: An empirical test of Deutsch's transactionalist theory. European Journal of Political Research, 50(6), 811 - 837. https://doi.org/10.1111/j.1475-6765.2011.01987.x

[16] Kuhn, T. (2019). Grand theories of european integration revisited: Does identity politics shape the course of European Integration? Journal of European Public Policy, 26(8), 1213 - 1230. https://doi.org/10.1080/13501763.2019.1622588

[17] Mackinnon, D., \& Cumbers, A. (2007). An introduction to economic geography: globalisation, uneven development and place. Essex: Pearson Education Limited.

[18] Mansfield, E. D., \& Mutz, D. C. (2009). Support for Free Trade: Self-interest, sociotropic politics, and out-group anxiety. International Organization, 63(3), 425 457. https://doi.org/10.1017/s0020818309090158

[19] Miller, B. (2012). Exploring the economic determinants of immigration attitudes. Poverty \& Public Policy, 4(2), 1 - 19. https://doi.org/10.1515/1944-2858.1248

[20] Singh, A. (1997). Liberalization and globalisation: An unhealthy euphoria. In Michie, J. - Grieve-Smith, J. (eds.). Employment and Economic Performance: Jobs, Inflation and Growth. New York: Oxford University Press, $11-35$. 
[21] Schmölz, B. (2019). Misunderstanding, conflict and divisions between the Visegrad Group and the European Union: an analytical discourse beyond the public cliche of the migration crisis. CES Working Papers, Alexandru Ioan Cuza University of Iasi, Centre for European Studies, Iasi, 11(1), $22-34$.

[22] Swiss Economic Institute. (2021). KOF Globalisation Index. Available at: https://kof. ethz.ch/en/forecasts-and-indicators/indicators/kof-globalisation-index.html

[23] Tereszkiewicz, F. (2018). Visegrad Euroscepticism: Discursive nodal points in Eurosceptic discourses surrounding external actions of the European Union. On-Line Journal Modelling the New Europe, (26), 144 - 168.

https://doi.org/10.24193/ojmne.2018.26.10

[24] Végh, Zs. (2018). From Pro-European Alliance to Eurosceptic Protest Group? The case of the Visegrad Group. Swedish Institute for European Policy Analysis. Available at: $\quad$ https://www.sieps.se/en/publications/2018/from-pro-european-alliance-toeurosceptic-protest-group-the-case-of-the-visegrad-group/

[25] Vries, C., \& Hoffman, I. (2016). Fears not Values. Public Opinion and the Populist Vote in Europe. Bertelsmann Stiftung. Available at: https://www.bertelsmann-stiftung. de/fileadmin/files/user_upload/EZ_eupinions_Fear_Study_2016_ENG.pdf

[26] White, R. (2017). Public Opinion on Economic Globalization: Considering Immigration, International Trade, and Foreign Direct Investment. Springer. 